ORIGINAL ARTICLE

\title{
Aromatic profiling of flavor active \\ compounds in sugarcane spirits aged in tropical wooden barrels
}

\author{
Perfil aromático de compostos ativos de aroma em destilados \\ de cana-de-açúcar envelhecidos em barris de madeiras \\ tropicais
}

\author{
Aline Marques Bortoletto, Giovanni Casagrande Silvello ${ }^{1}$, André Ricardo Alcarde ${ }^{1 *}$ (i) \\ 'Universidade de São Paulo (USP), Escola Superior de Agricultura "Luiz de Queiroz" (ESALQ), Departamento de \\ Agroindústria, Alimentos e Nutrição, Piracicaba/SP - Brasil
}

${ }^{*}$ Corresponding Author: André Ricardo Alcarde, Universidade de São Paulo (USP), Escola Superior de Agricultura "Luiz de Queiroz" (ESALQ), Departamento de Agroindústria, Alimentos e Nutrição, Av. Pádua Dias, 11, CEP: 13418-900, Piracicaba/SP - Brasil, e-mail: andre.alcarde@usp.br

Cite as: Bortoletto, A. M., Silvello, G. C., \& Alcarde, A. R. (2021). Aromatic profiling of flavor active compounds in sugarcane spirits aged in tropical wooden barrels. Brazilian Journal of Food Technology, 24, e2019071. https://doi.org/10.1590/1981-6723.07119

\begin{abstract}
The production of high quality spirits implies an aging period in wooden barrels, resulting in numerous physicochemical reactions between the wood and the beverage. Oak is the main wood used in the aging process of alcoholic beverages worldwide. However, in Brazil, the use of tropical wood species can be a viable option, allowing for innovation in the characteristics of spirits. This study aimed to determine the aromatic profiling of flavor active compounds in Brazilian sugarcane spirit (cachaça) after a 12-month aging period in new 225-L toasted and non-toasted barrels made from the tropical wood species cerejeira [Amburana cearensis (Fr. Allem.) A.C. Smith], castanheira (Bertholletia excelsa Humboldt \& Bonpland), and cabreúva (Myrocarpus frondosus Allemão). The chemical characterization was carried out using the Gas-Chromatography/Mass Spectroscopy (GC/MS) scan mode, and the identification targeted on flavor active compounds (esters, alcohols, organic acids, phenolic compounds, and terpenes). Toasted and non-toasted cerejeira barrels intensified the contents of phenolic compounds in cachaça. The samples aged in cerejeira barrels exhibited the most complex profile, mainly related to organic acids and phenolic compounds. However, cabreúva barrels transferred significant aromatic terpenes to cachaça. This research presented a novel focus on the aromatic profiling of flavor active compounds in cachaça aged in barrels made from tropical wood species.
\end{abstract}

Keywords: Distilled spirits; Aging marker compounds; Aging; Toasted barrels; Cachaça; Sugarcane.

\section{Resumo}

A produção de bebidas destiladas de qualidade envolve um período de envelhecimento em barris de madeira, durante o qual diversas reações físico-químicas ocorrem entre a madeira e o destilado. O carvalho é a principal madeira empregada mundialmente no processo de envelhecimento de bebidas alcoólicas. Entretanto, no Brasil, o 
uso de espécies de madeiras tropicais pode ser uma opção viável por permitir inovação nas características de destilados. O objetivo deste estudo foi determinar o perfil aromático de compostos de aromas em aguardente de cana (cachaça) envelhecida por 12 meses em barris novos de $225 \mathrm{~L}$, com e sem tosta, construídos com espécies de madeiras tropicais: cerejeira [Amburana cearensis (Fr. Allem.) A.C. Smith], castanheira (Bertholletia excelsa Humboldt \& Bonpland) e cabreúva (Myrocarpus frondosus Allemão). A caracterização química foi realizada por meio de cromatografia gasosa/espectrometria de massas, no modo scan, visando identificar compostos de aromas (ésteres, álcoois, ácidos orgânicos, compostos fenólicos e terpenos). Tanto os barris tostados quanto os sem tosta aumentaram a concentração de compostos fenólicos nas cachaças. Os destilados envelhecidos em cerejeira apresentaram maior complexidade aromática, principalmente devido aos ácidos orgânicos e aos compostos fenólicos. Os barris de cabreúva forneceram maiores teores de terpenos aromáticos aos destilados. Esta pesquisa apresenta um novo enfoque no perfil aromático de compostos de aroma em cachaça envelhecida em barris de madeiras tropicais.

Palavras-chave: Bebidas destiladas; Compostos marcadores de envelhecimento; Envelhecimento; Tosta de barris; Cachaça; Cana-de-açúcar.

\section{Introduction}

Cachaça is the exclusive denomination of the Brazilian spirit produced by distillation of fermented sugarcane juice, with $38-48 \%$ alcohol by volume (ABV) at $20^{\circ} \mathrm{C}$ (Brasil, 2005). The process of production of cachaça has not yet been standardized in terms of sugarcane varieties, fermentation conditions, or distillation equipment. These variations may lead to the production of different flavor compounds during the fermentation and distillation processes and, consequently, affect the sensory profile of this beverage. Cachaça distillation may be carried out either in copper pot stills or in continuous columns, and aging in wooden barrels is optional.

Brazilian laws established four types of cachaça as following: white; aged; premium; and extrapremium. White cachaça is bottled directly from distillation. Aged cachaça is matured for one year in wooden barrels and then it can be mixed with $50 \%$ of white cachaça. Premium cachaça is aged for one year and cannot be mixed. Extra-premium cachaça must be kept in barrels for at least three years (Brasil, 2005). The Brazilian Ministry of Agriculture, Livestock, and Food Supply considers that, in addition to oak, the use of some tropical wood species is safe for manufacturing barrels with the purpose of aging cachaça (Brasil, 2016).

The chemical composition of cachaça is very complex, similarly to all kinds of distilled spirits. Different kinds of compounds have been considered responsible for the aroma and flavor of cachaça such as alcohols, aldehydes, esters, terpenes, fatty acids, and phenols (Brasil, 2016). Since cachaça is a complex mixture of some hundreds of flavor compounds in an ethanol-water matrix, several factors affect its physicochemical and organoleptic composition, namely sugarcane variety, cultivation region, harvesting process, juice extraction, yeast strain, fermentation conditions, distillation, and aging. Therefore, both the genesis and transformation of aroma compounds result from biochemical (sugarcane and fermentation) and chemical (distillation and aging) reactions (Bortoletto \& Alcarde, 2013).

Maturation in wooden barrels promotes the aeration of the alcoholic beverage so that it achieves balance and stability. These interactions contribute to the richness and complexity of the aromatic bouquet and, consequently, add value to the spirits. Aging is the main factor that affects the characterization of distilled spirits, given that approximately $60 \%$ of the aromatic compounds come from wood components and constituents as well as from the interaction of the alcoholic beverage components with the wood extractives, while the remaining 40\% originate from the production process (Mosedale \& Puech, 1998).

During the aging process, certain compounds such as tannins, cinnamic and benzoic aldehydes and benzoic acids are extracted from the wooden barrel (Puech, 1981). The identification of aromatic 
compounds in cachaça aged in wooden barrels of different origins allows the characterization of the beverage. The wood species and its physicochemical properties influence the maturation process of distilled spirits, which also depends on the geographic origin of the wood, aging time, size and form of construction of the barrels, toasting treatment, finishing provided by cooperage, and number of times the barrel has been previously used (Mosedale, 1995).

Due to well-known and valuable characteristics, oak has long been employed in the aging process of alcoholic beverages worldwide. Nevertheless, in Brazil, the use of tropical wood species can be a viable option for generating innovative products with exotic appeal and sensory effects. Studies have shown the great potential of Brazilian wood species to produce aged spirits. The most used and investigated species are amendoim-bravo (Pterogyne nitens Tul), jequitibá [Cariniana estrellensis (Raddi) Kuntze], araruva (Centrolobium tomentosum Guillemin ex Benth.), cabreúva (Mycrocarpus frondosus Allemão), jequitibá rosa [Cariniana legalis (Mart.) Kuntze], cerejeira [Amburana cearensis (Fr. Allem.) A.C. Smith], paupereira (Platycyamus regnelli Benth.), grápia [Apuleia leiocarpa (Vogel) J.F. Macbr.], ipê roxo [Tabebuia heptaphylla (Vell.) Toledo], castanheira (Bertholletia excelsa Humboldt \& Bonpland), and freijó (Cordia goeldiana Huber) (Alcarde et al., 2010; Bortoletto \& Alcarde, 2013; Campos et al., 2004).

The technique employed to characterize the aromatic profile of aged distilled spirits is an unbiased, nonsegmented, and multicomponent analysis that discriminates the profile obtained followed by the selection of specific markers. Aromatic compounds are responsible for the spirit flavor and considered important markers for the authenticity by detecting specific compounds within a group of similar samples.

Different wood species can transfer to the spirit several specific compounds derived from their structure and composition. Consequently, the aromatic profile analysis in aged spirits aims to identify particular and minor compounds (esters, alcohols, organic acids, phenolic compounds, and terpenes), which hold great aromatic contribution to the spirit flavor. This study aimed to determine the aromatic profile of cachaça aged in new toasted and non-toasted barrels made from different tropical wood species.

\section{Materials and methods}

\subsection{Cachaça production}

The cachaça used in this study was produced in the distillery of the Department of Agri-Food Industry, Foods and Nutrition, Escola Superior de Agricultura "Luiz de Queiroz", Universidade de São Paulo (USP). The wort was prepared using sugarcane variety SP 81-3250. Sugarcane juice was extracted using a stainless steel presser, and fermentation was carried out in 1,500 L tanks using Saccharomyces cerevisiae strain CA-11 (LNF Latinoamericana, Bento Gonçalves, RS, Brazil) for $24 \mathrm{~h}$ at $30^{\circ} \mathrm{C}$. Double distillation was carried out in a 1,000-L copper pot still, based on the method used in the production of whiskey (Piggott \& Conner, 2003).

\subsection{Aging process}

Barrels made from the three main tropical wood species usually used for aging cachaça in Brazil, cerejeira, castanheira, and cabreúva were acquired from Tanoaria Mezacasa (Monte Belo do Sul, RS, Brazil), totaling 18 220-L barrels (six from each wood species). Toasting $\left(240{ }^{\circ} \mathrm{C}\right.$ for $12 \mathrm{~min}$ ) was applied to three barrels from each species, and the others remained non-toasted. All barrels were washed and filled with water for $24 \mathrm{~h}$ prior to use. After draining the water, the barrels were filled with cachaça $(55 \% \mathrm{ABV})$, which was aged for 12 months at room temperature $\left(22 \pm 5^{\circ} \mathrm{C}\right), 55 \pm 10 \%$ relative humidity, and protected from vibrations. 


\subsection{Chemical profiling}

Samples were taken from the barrels and filtered in Millex-HV filters (Millipore SAS, Molsheim, France) with polyvinylidene difluoride (PVDF) membrane (13 $\mathrm{mm}$ diameter, $0.45 \mu \mathrm{m}$ pore size) prior to injecting in liquid phase directly into a Shimadzu Gas-Chromatography/Mass Spectroscopy (GC-MS) 2010 gas chromatograph with mass detector Shimadzu QP-2010 plus (Shimadzu Co., Kyoto, Japan), based on the methodology described by Cadahía et al. (2006). Aliquots of $1.0 \mu \mathrm{L}$ were automatically injected using the split mode (split ratio 1:5), in triplicate. The carrier gas was helium at a flow rate of $1 \mathrm{~mL} / \mathrm{min}$. Separation of compounds was performed using a capillary column with polar phase (esterified polyethylene glycol) HP-FFAP $(49 \mathrm{~m} \times 0.20 \mathrm{~mm} \times 0.33 \mu \mathrm{m})$. The injector and detector were kept at 180 ${ }^{\circ} \mathrm{C}$ and $220^{\circ} \mathrm{C}$, respectively. The following temperature program was applied to the oven: starting at $35^{\circ} \mathrm{C}$ for $3 \mathrm{~min}$; increasing to $250{ }^{\circ} \mathrm{C}$ at a rate of $15{ }^{\circ} \mathrm{C} / \mathrm{min}$; and remaining at $250{ }^{\circ} \mathrm{C}$ for $5 \mathrm{~min}$. The identification, in scan mode $(\mathrm{m} / \mathrm{z}=40$ to 400$)$, targeted on flavor active compounds (esters, alcohols, organic acids, phenolic compounds, and terpenes) based on the similarity index ( $\mathrm{SI} \geq 85 \%$ ) of the libraries Flavors and Fragrances of Natural and Synthetic Compounds - Mass Spectral Database (FFNSC) and Wiley Registry of Mass Spectral Data 8 (Wiley 8). The percentage of each compound was determined according to the peak area in the chromatograms obtained for each analysis.

The statistical analyses were performed using Analysis of Variance (ANOVA) and the Statistical Analysis System (SAS/STAT), version 9.3. The Tukey's test $(p \geq 0.05)$ was applied to compare the means of the results obtained from triplicate analyses.

\section{Results and discussion}

Wood species and toasting process conferred different specific aromatic compounds to the aged cachaça, which made it possible to distinguish these spirits based on their chemical profiles (Figure 1). The analyses showed that 60 aromatic compounds intensely contributed to the chemical profile of cachaça aged for 12 months in barrels made from Brazilian wood species (Table 1). Esters, alcohols, acids, phenolic compounds, and terpenes contributed to the production of aged cachaça with different aromatic profiles.

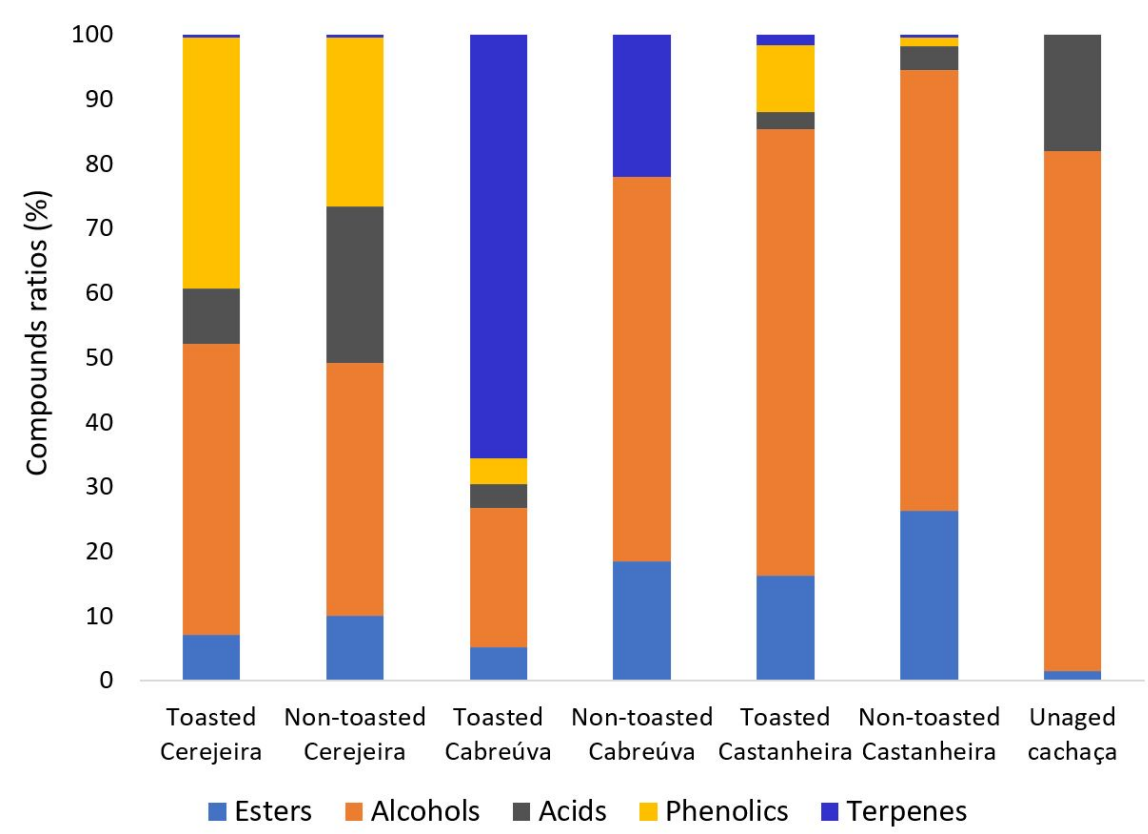

Figure 1. Ratios of aromatic compounds detected in cachaça aged for 12 months in new toasted and non-toasted barrels made from Brazilian tropical wood species. 
Aromatic profiling of flavor active compounds in sugarcane spirits aged in tropical wooden barrels

Bortoletto, A. M. et al.

Table 1. Aromatic profile of cachaça aged for 12 months in new toasted and non-toasted barrels made from Brazilian tropical wood species.

\begin{tabular}{|c|c|c|c|c|c|c|c|c|}
\hline \multirow{2}{*}{ Compounds } & \multirow{2}{*}{ Descriptors $^{1}$} & \multicolumn{2}{|c|}{$\begin{array}{c}\text { Cerejeira barrel } \\
(\text { area \%) }\end{array}$} & \multicolumn{2}{|c|}{$\begin{array}{l}\text { Cabreúva barrel } \\
(\text { area \%) }\end{array}$} & \multicolumn{2}{|c|}{$\begin{array}{c}\text { Castanheira barrel } \\
(\text { area \%) })^{2}\end{array}$} & \multirow{2}{*}{$\begin{array}{l}\text { Unaged } \\
\text { cachaça } \\
(\text { area \%) }\end{array}$} \\
\hline & & Toasted & $\begin{array}{l}\text { Non- } \\
\text { toasted }\end{array}$ & Toasted & $\begin{array}{l}\text { Non- } \\
\text { toasted }\end{array}$ & Toasted & $\begin{array}{l}\text { Non- } \\
\text { toasted }\end{array}$ & \\
\hline \multicolumn{9}{|c|}{ Esters } \\
\hline Ethyl acetate & Solvent, pineapple & $5.44^{\mathrm{b}}$ & $3.74^{\mathrm{c}}$ & $2.93^{\mathrm{c}}$ & $5.72^{b}$ & $10.61^{\mathrm{a}}$ & $10.93^{\mathrm{a}}$ & $1.13^{\mathrm{d}}$ \\
\hline Ethyl butanoate & Pineapple & $0.09^{\mathrm{a}}$ & $0.06^{\mathrm{a}}$ & & & & & $0.02^{b}$ \\
\hline Ethyl hexanoate & Fruity, sweety, anise & $0.11^{\mathrm{a}}$ & & & & & $0.19^{\mathrm{a}}$ & \\
\hline Ethyl linolate & Fatty, hay & $0.23^{b}$ & $2.50^{\mathrm{a}}$ & $0.18^{b}$ & $0.75^{b}$ & & & \\
\hline Ethyl heptadecanoate & Fruity & 0.06 & & & & & & \\
\hline Ethyl octadecanoate & $\begin{array}{c}\text { Fruity, wine, waxy, } \\
\text { sweet, apricot, banana, } \\
\text { brandy, pear }\end{array}$ & $0.11^{b}$ & $0.65^{\mathrm{a}}$ & & & $0.22^{b}$ & & \\
\hline Methyl octadecadienoate & Oily, fatty & $0.26^{\mathrm{a}}$ & & & & $0.59^{\mathrm{a}}$ & $0.43^{\mathrm{a}}$ & \\
\hline Ethyl hexadecanoate & Fatty, rancid & $0.73^{b}$ & $0.40^{\mathrm{c}}$ & $0.94^{b}$ & $3.17^{\mathrm{a}}$ & $1.27^{b}$ & $1.27^{b}$ & \\
\hline Isoamyl acetate & Banana & & 0.04 & & & & & \\
\hline Ethyl octanoate & Fruity, lemon, anise & & $0.51^{\mathrm{c}}$ & $0.35^{\mathrm{c}}$ & $0.94^{\mathrm{b}}$ & $1.15^{\mathrm{b}}$ & $1.84^{\mathrm{a}}$ & $0.12^{d}$ \\
\hline Ethyl decanoate & Leaf, grape & & $0.97^{\mathrm{b}}$ & $0.70^{\mathrm{b}}$ & $2.00^{\mathrm{a}}$ & $2.22^{\mathrm{a}}$ & $2.24^{\mathrm{a}}$ & $0.16^{\mathrm{c}}$ \\
\hline 2-hexyl acetate & $\begin{array}{l}\text { Fruity, green, apple, } \\
\text { banana, sweet }\end{array}$ & & 0.07 & & & & & \\
\hline Isoeugenol methyl ester & $\begin{array}{c}\text { Spicy, clove, resinous, } \\
\text { woody }\end{array}$ & & 0.05 & & & & & \\
\hline Ethyl methanoate & $\begin{array}{l}\text { Ethereal, green, alcohol, } \\
\text { rose, cognac }\end{array}$ & & $0.68^{\mathrm{c}}$ & & $5.93^{b}$ & & $7.90^{\mathrm{a}}$ & \\
\hline $\begin{array}{c}\text { Butadienoic acid methyl } \\
\text { ester }\end{array}$ & Oily, fatty & & & & & 0.06 & & \\
\hline Ethyl dodecanoate & $\begin{array}{l}\text { Sweet, waxy, floral, } \\
\text { soapy, clean }\end{array}$ & & & & & & 1.27 & \\
\hline \multicolumn{9}{|c|}{ Alcohols } \\
\hline Isobutanol & Sweet, chemical & $0.81^{\text {a }}$ & $0.85^{\mathrm{a}}$ & & & & $0.94^{\mathrm{a}}$ & \\
\hline 1-butanol & Pungent, alcoholic & $0.09^{\mathrm{a}}$ & $0.09^{\mathrm{a}}$ & & & & & \\
\hline Isoamyl alcohol & $\begin{array}{l}\text { Bitter, fusel, whiskey, } \\
\text { malt, burn }\end{array}$ & $41.86^{\mathrm{c}}$ & $33.89^{\mathrm{c}}$ & $20.76^{d}$ & $57.98^{b}$ & $66.12^{b}$ & $65.98^{b}$ & $77.21^{\mathrm{a}}$ \\
\hline Benzyl alcohol & $\begin{array}{l}\text { Floral, rose, phenolic, } \\
\text { sweet, balsamic, fruity }\end{array}$ & $0.12^{\mathrm{a}}$ & $2.80^{b}$ & & & & & \\
\hline Phenylethyl alcohol & Floral, sweet, rose & $1.87^{b}$ & $0.94^{\mathrm{c}}$ & $0.93^{c}$ & $1.48^{\mathrm{b}}$ & $1.98^{\mathrm{b}}$ & $1.62^{\mathrm{b}}$ & $2.88^{\mathrm{a}}$ \\
\hline
\end{tabular}


Aromatic profiling of flavor active compounds in sugarcane spirits aged in tropical wooden barrels

Bortoletto, A. M. et al.

Table 1. Continued...

\begin{tabular}{|c|c|c|c|c|c|c|c|c|}
\hline \multirow{2}{*}{ Compounds } & \multirow{2}{*}{ Descriptors $^{1}$} & \multicolumn{2}{|c|}{$\begin{array}{l}\text { Cerejeira barrel } \\
(\text { area \%) })^{2}\end{array}$} & \multicolumn{2}{|c|}{$\begin{array}{l}\text { Cabreúva barrel } \\
(\text { area \%) }\end{array}$} & \multicolumn{2}{|c|}{$\begin{array}{l}\text { Castanheira barrel } \\
\quad(\text { area \%) }\end{array}$} & \multirow{2}{*}{$\begin{array}{c}\text { Unaged } \\
\text { cachaça } \\
(\text { area } \%)^{2}\end{array}$} \\
\hline & & Toasted & $\begin{array}{c}\text { Non- } \\
\text { toasted }\end{array}$ & Toasted & $\begin{array}{c}\text { Non- } \\
\text { toasted }\end{array}$ & Toasted & $\begin{array}{c}\text { Non- } \\
\text { toasted }\end{array}$ & \\
\hline \multicolumn{9}{|c|}{ Carboxylic Acids } \\
\hline Formic acid & Pungent & $2.78^{\mathrm{b}}$ & $2.06^{\mathrm{b}}$ & $1.65^{\mathrm{b}}$ & & & & $6.15^{\mathrm{a}}$ \\
\hline Propanoic acid & $\begin{array}{l}\text { Vinegar, pungent, acidic, } \\
\text { dairy-like }\end{array}$ & $0.12^{\mathrm{a}}$ & $0.11^{\mathrm{a}}$ & $0.16^{\mathrm{a}}$ & & $0.21^{\mathrm{a}}$ & & \\
\hline Decanoic acid & Fatty acid, cheesy & $1.30^{\mathrm{b}}$ & & $0.91^{\mathrm{b}}$ & & $1.94^{\mathrm{a}}$ & $1.71^{\mathrm{a}}$ & $0.81^{\mathrm{b}}$ \\
\hline Butanoic acid & Cheesy, rancid, cheesy & $0.21^{\mathrm{a}}$ & $0.18^{\mathrm{a}}$ & & & $0.25^{\mathrm{a}}$ & $0.22^{\mathrm{a}}$ & $0.11^{\mathrm{b}}$ \\
\hline Pentanoic acid & Sweaty, rancid & 0.09 & & & & & & \\
\hline Hexanoic acid & Fatty acid, sweaty & $0.15^{\mathrm{a}}$ & $0.13^{\mathrm{a}}$ & & & $0.20^{\mathrm{a}}$ & $0.16^{\mathrm{a}}$ & \\
\hline Heptanoic acid & Cheesy, & $0.07^{\mathrm{b}}$ & $0.16^{\mathrm{b}}$ & $0.45^{\mathrm{a}}$ & & & & \\
\hline Octanoic acid & Cheesy, manure, sweaty & $0.86^{\mathrm{a}}$ & & & & & $1.12^{\mathrm{a}}$ & $0.95^{\mathrm{a}}$ \\
\hline Benzeneformic acid & Pungent & $0.10^{\mathrm{b}}$ & $0.05^{\mathrm{b}}$ & $0.42^{\mathrm{a}}$ & & & & \\
\hline Dodecanoic acid & Fatty acid & 1.21 & & & & & & \\
\hline 3-methylpentanoic acid & Sweaty, rancid & & 0.06 & & & & & \\
\hline Pentadecanoic acid & Waxy & $0.59^{\mathrm{a}}$ & $0.56^{\mathrm{a}}$ & & & & & \\
\hline Hexadecanoic acid & $\begin{array}{l}\text { Waxy, creamy, fatty, } \\
\text { soapy, dairy }\end{array}$ & $0.75^{\mathrm{a}}$ & $0.60^{\mathrm{a}}$ & & & & $0.50^{\mathrm{a}}$ & \\
\hline Benzoic acid & Fruity, cherry & & $15.28^{\mathrm{a}}$ & & & & & $9.98^{\mathrm{b}}$ \\
\hline Tetradecanoic acid & $\begin{array}{l}\text { Waxy, fatty, soapy, } \\
\text { cheesy }\end{array}$ & & 0.04 & & & & & \\
\hline Octadecenoic acid & Oily, waxy, fried & & 0.86 & & & & & \\
\hline Octadecadienoic acid & Faint, fatty & & 1.01 & & & & & \\
\hline \multicolumn{9}{|c|}{ Phenolics } \\
\hline$\beta$-angelica lactone & $\begin{array}{l}\text { Herbal, sweet, anisic, } \\
\text { nutty }\end{array}$ & $0.61^{\mathrm{a}}$ & $0.47^{\mathrm{a}}$ & & & & & \\
\hline Guaiacol & Animal, phenol & $2.78^{\mathrm{a}}$ & & & & $0.66^{\mathrm{b}}$ & $0.40^{\mathrm{b}}$ & \\
\hline P-cresol (4-methylfenol) & Medicinal & $0.30^{\mathrm{b}}$ & $0.74^{\mathrm{a}}$ & & & & & \\
\hline 2,3-xylenol & $\begin{array}{l}\text { Phenolic, chemical, } \\
\text { musty }\end{array}$ & $0.10^{\mathrm{b}}$ & $0.31^{\mathrm{a}}$ & & & & & \\
\hline P-vinylguaiacol & Burned, smoky, spicy & $0.07^{\mathrm{a}}$ & $0.02^{\mathrm{b}}$ & & & & & \\
\hline Syringol & Bacon & $0.28^{\mathrm{c}}$ & $1.70^{\mathrm{a}}$ & $0.22^{\mathrm{c}}$ & & $0.75^{b}$ & $0.41^{\mathrm{b}}$ & \\
\hline Methyl anthranilate & $\begin{array}{l}\text { Sweet, fruity, grape, } \\
\text { musty, berry }\end{array}$ & $7.03^{\mathrm{a}}$ & $4.35^{\mathrm{b}}$ & $2.61^{\mathrm{c}}$ & & $8.23^{\mathrm{a}}$ & & \\
\hline
\end{tabular}


Aromatic profiling of flavor active compounds in sugarcane spirits aged in tropical wooden barrels

Bortoletto, A. M. et al.

Table 1. Continued...

\begin{tabular}{|c|c|c|c|c|c|c|c|c|}
\hline \multirow{2}{*}{ Compounds } & \multirow{2}{*}{ Descriptors ${ }^{1}$} & \multicolumn{2}{|c|}{$\begin{array}{c}\text { Cerejeira barrel } \\
(\text { area \%) })^{2}\end{array}$} & \multicolumn{2}{|c|}{$\begin{array}{l}\text { Cabreúva barrel } \\
\quad(\text { area \%) }\end{array}$} & \multicolumn{2}{|c|}{$\begin{array}{l}\text { Castanheira barrel } \\
\quad(\text { area \%) })^{2}\end{array}$} & \multirow{2}{*}{$\begin{array}{c}\text { Unaged } \\
\text { cachaça } \\
(\text { area \%) }\end{array}$} \\
\hline & & Toasted & $\begin{array}{l}\text { Non- } \\
\text { toasted }\end{array}$ & Toasted & $\begin{array}{l}\text { Non- } \\
\text { toasted }\end{array}$ & Toasted & $\begin{array}{l}\text { Non- } \\
\text { toasted }\end{array}$ & \\
\hline Coumarin & $\begin{array}{c}\text { Tonka bean (Dipteryx } \\
\text { odorata) }\end{array}$ & $19.08^{\mathrm{a}}$ & $17.75^{\mathrm{a}}$ & $0.51^{\mathrm{b}}$ & & & & \\
\hline Hydrocoumarin & $\begin{array}{l}\text { Sweet, creamy, coconut, } \\
\text { vanilla, spicy }\end{array}$ & $8.08^{\mathrm{a}}$ & $0.46^{\mathrm{b}}$ & $0.69^{\mathrm{b}}$ & & $0.55^{\mathrm{b}}$ & $0.41^{\mathrm{b}}$ & \\
\hline Methoxyeugenol & $\begin{array}{l}\text { Sweet, spicy, clove, } \\
\text { woody, phenolic }\end{array}$ & 0.12 & & & & & & \\
\hline Vanillin & Vanilla, sweet, floral & $0.43^{\mathrm{b}}$ & $1.06^{\mathrm{a}}$ & & & $0.68^{\mathrm{b}}$ & & \\
\hline Vanillic acid & Sweet, creamy, vanilla & $0.27^{\mathrm{b}}$ & $2.68^{\mathrm{a}}$ & & & & & \\
\hline & & & Terpen & & & & & \\
\hline Farnesol & Medicinal & $0.44^{\mathrm{c}}$ & $0.36^{\mathrm{c}}$ & $1.27^{\mathrm{a}}$ & & $0.75^{\mathrm{b}}$ & $0.46^{\mathrm{c}}$ & \\
\hline Nerolidol & Rose, woody & & & $60.24^{\mathrm{a}}$ & & $0.81^{\mathrm{b}}$ & & \\
\hline Sesquisabinene & Balsamic, grassy, woody & & & $0.23^{b}$ & $0.62^{\mathrm{a}}$ & & & \\
\hline$\alpha$-elemol & $\begin{array}{l}\text { Spicy, citrus, woody, } \\
\text { resinous }\end{array}$ & & & $0.33^{b}$ & $14.74^{\mathrm{a}}$ & & & \\
\hline$\alpha$-bisabolol & $\begin{array}{l}\text { Mild, floral, peppery, } \\
\text { clean }\end{array}$ & & & $3.24^{\mathrm{a}}$ & $3.36^{\mathrm{a}}$ & & & \\
\hline$\alpha$-cadinol & Herbal, woody & & & $0.29^{\mathrm{b}}$ & $1.84^{\mathrm{a}}$ & & & \\
\hline Linalool & Flowery, muscat & & & & 0.85 & & & \\
\hline Torulosol & Tea, herbal & & & & 0.62 & & & \\
\hline \multicolumn{9}{|c|}{ Other compounds } \\
\hline 5-hidroxymethyl furfural & Aldehyde, caramel & $0.18^{\mathrm{b}}$ & & & & $0.75^{\mathrm{a}}$ & & \\
\hline Furfural & $\begin{array}{l}\text { Sweet, fruit, floral, } \\
\text { sweety }\end{array}$ & 0.23 & & & & & & \\
\hline
\end{tabular}

Numbers followed by different letters in the same line are statistically different by the Tukey's test $(p<0.05) .{ }^{1}$ The Good Scents Company Information System (2019). ${ }^{2}$ Area $\%=\%$ of chromatogram peak areas.

The compounds in unaged cachaça were $81 \%$ of alcohols ( $96 \%$ isoamyl alcohol), $18 \%$ of acids $(55 \%$ of benzoic acid and $34 \%$ of formic acid), and $1 \%$ of esters (79\% of ethyl acetate) (Figure 1). Obviously, the unaged cachaça did not display phenolics or terpenes.

The barrels influenced the chemical composition of flavor compounds and conferred more complexity to aged spirits (Table 1). Wood species also influenced the number of total compounds detected in aged cachaça. Barrels made from cerejeira conferred more than 50 compounds to cachaça. In cachaça aged in cerejeira toasted barrels, 40 different compounds were detected, whereas in cachaça aged in cerejeira untoasted barrels, 41 different compounds were detected, some of them only in this sample. Barrels made from cabreúva contributed with 25 compounds, whereas barrels made from castanheira contributed with 27 compounds. Cerejeira could provide more flavor compounds to spirits because this type of wood is rich in extractable compounds and the wood composition and structure allow a better extraction by ethanol and oxidation (Aquino et al., 2005). 
In spite of non-toasted barrels also influenced the chemical composition of the spirits, the intensity of thermal degradation influences both the physical characteristics of wood, due to an increase in porosity and surface, and its chemical characteristics, generating new compounds and making their extraction by the beverage easier. Because of the interaction with wood, the distilled spirit has its sensory features transformed, increasing its aroma complexity (Mosedale \& Puech, 1998).

Comparing the mass spectra here obtained to reference databases, 168 volatile organic compounds were identified in aged Brazilian cachaça, including alcohols, aldehydes, esters, and acetates (Cardeal \& Marriott, 2009). Aged cachaça exhibited even more compounds that contributed to its distinctive flavor, mainly terpenes, whose origin could be attributed to components extracted from wood or reactions between the compounds of cachaça and the wooden barrels.

More than 175 compounds have been identified in tequila, and among those that contributed to its flavor are alcohols (sweet and floral odors) and esters (pleasant fruity flavors) (Benn \& Peppard, 1996). In brandies, 144 compounds have been identified, mainly esters and alcohols such as isobutanol, 3-methyl butanol, 1-hexanol, ethyl octanoate, and ethyl decanoate (Zhao et al., 2009). In plum brandies, 195 compounds have been detected, including unsaturated fusel alcohols, unsaturated aldehydes, and monoterpenes (Vyviurska et al., 2017).

\subsection{Esters}

In the aged cachaça obtained in this study, 16 esters were identified (Table 1). Castanheira and cabreúva promoted the greatest presence of total esters (Table 1). Ethyl acetate, ethyl hexadecanoate, ethyl octanoate, and ethyl decanoate were common to all cachaça samples aged in non-toasted barrels. Non-toasted barrels also conferred cachaça higher contents of total esters. Esters are considered the major group of flavor compounds and ethyl acetate is the principal representative of this category present in distilled spirits (Lee et al., 2001).

Ethyl acetate was the predominant ester in all samples (Table 1). Cachaça aged in castanheira barrels displayed higher contents of ethyl acetate. Castanheira wood has a relatively low density $\left(0.55-0.70 \mathrm{~g} / \mathrm{cm}^{3}\right)$ and large diffuse pores, in 1 to 4 vessels $/ \mathrm{mm}^{2}$ (Richter \& Dallwitz, 2019). The permeability of oxygen through the wood may have promoted a more intense oxidation of the distilled spirit and, consequently, higher contents of ethyl acetate were found in cachaça aged in castanheira barrels.

Ethyl acetate is formed by the esterification reaction between ethanol and acetic acid produced during fermentation, during the maturation period due to oxidation (Singleton, 1995), and may also be extracted from the wood that has been degraded by heating during the toasting and charring processes (Campos et al., 2004).

Ester formation may be influenced by many factors such as fermentation temperature, oxygen availability, and yeast strain (Madrera et al., 2003; Steger \& Lambrechts, 2000). Higher temperatures increase the rates of hydrolysis and volatilization leading to a greater loss of esters. On the contrary, lower fermentation temperatures allow the formation of short-chain esters (Fan \& Qian, 2006). Most esters have a typical "fruity" and "floral" aroma, contributing to the development of fruity, sweet, apple, pineapple, and floral odors in spirits (Ferrari et al., 2004; Ugliano \& Moio, 2005).

In the volatile fraction of Bourbon whiskey, 13 minor aroma compounds were detected by GColfactometry (GC-O) (Poisson \& Schieberle, 2008). Straight-chain ethyl esters such as ethyl acetate, ethyl butanoate, ethyl hexanoate, and ethyl octanoate are very important to Bourbon aromas because of their presence in relatively high contents.

In the present study, toasting was ineffective in promoting the formation of esters in cachaça aged in castanheira and cabreúva barrels. Conversely, toasting had great influence on cerejeira barrels, probably because the structure and porosity of this type of wood favored a higher thermal degradation of certain compounds during the toasting process (Aquino et al., 2005). The mainly aromatic notes related to ethyl acetate in spirits are solvent, fruity, and pineapple (Lee et al., 2001; Xu \& Ji, 2012). 
Other minor esters were found in cachaça aged in non-toasted cerejeira barrels (Table 1). These compounds are involved in high complexity sensory profiles (Janzantti, 2004). In addition, they also improve flavor due to their synergism with some other aroma compounds (Nykänen \& Nykänen, 1991). The most relevant minor esters present in aged cachaça were ethyl methanoate, ethyl linolate, ethyl hexadecanoate, ethyl octanoate, and 2-hexyl acetate.

\subsection{Alcohols}

Alcohols greatly influenced cachaça aged in all barrels, particularly in those made from castanheira (Table 1). Alcohols can be produced during sugar and amino acid fermentation, and also through reduction of the corresponding aldehydes by yeast during the fermentation process (Fan \& Qian, 2006).

A total of six types of alcohol were identified in aged cachaça, two of them common to all samples. Isoamyl alcohol predominated, accounting for more than $95 \%$ of total alcohol content. The flavors they confer to spirits are bitter, fusel, whiskey, malt, and burn notes (Stevens, 1991).

Toasting had no influence on the content of minor alcohols in cachaça. The most important minor alcohols in all samples were isoamyl alcohol and phenylethyl alcohol. The presence of phenylethyl alcohol explained the "rose" descriptor in freshly distilled cognac (Ferrari et al., 2004).

High alcohols containing up to five carbon atoms contribute to the formation of the aromatic bouquet in spirits, especially amyl alcohols. Nevertheless, an excess of higher alcohols negatively impacts the sensory quality of sugarcane spirits (Alcarde, 2017).

\subsection{Carboxylic acids}

A total of 17 acids were identified in aged cachaça (Table 1). All wood species promoted the formation of propanoic acid and decanoic acid in cachaça. The formation of acids occurs mainly due to the action of bacteria and yeast during fermentation, as well as ethanol oxidation and extraction during aging because of wood porosity. Each wood species exhibits a specific porosity resulting from the natural structure of the fibers and, consequently, some species can boost the volatile acidity of aged spirits (Bortoletto \& Alcarde, 2013). Cabreúva wood has a relatively high density $\left(0.84-0.91 \mathrm{~g} / \mathrm{cm}^{3}\right)$ and moderately numerous small pores (Richter \& Dallwitz, 2019). Cerejeira wood has the lowest density $\left(0.52-0.65 \mathrm{~g} / \mathrm{cm}^{3}\right)$ among the tested species (Richter \& Dallwitz, 2019), with large diffuse pores, in 2 to 6 vessels $/ \mathrm{mm}^{2}$, which probably allowed the permeability of oxygen through the wood. The consequent ethanol oxidation led to a relatively higher content of acids in cachaça aged in cerejeira barrels.

The sum of total acids was higher in cachaça aged in non-toasted cerejeira barrels (Table 1), and benzoic acid was the one that most contributed to this value $(15.3 \%)$. Some minor acids that influence the sensory aspects of cachaça such as formic, butanoic, hexanoic, and octanoic acids were identified.

Caprylic (octanoic) and capric (decanoic) acids have already been detected in aged cachaça (Campos et al., 2004), as well some terpenes, plant secondary metabolites with remarkable antioxidant, anticancer, and antiinflammatory properties. The formation of such terpenes may result from slow processes that arise during the maturation of alcoholic beverages in wooden barrels (Carando et al., 1999; Park et al., 1999).

\subsection{Phenolics}

Phenolic compounds are the major contribution of wood to spirits, and their contents increase during the maturation process (Mosedale \& Puech, 1998). The water-alcohol solution has the power to extract particular molecules from wood, specifically from lignin, cellulose, and hemicellulose. Guaiacyl and syringyl phenols generate aging markers. Among the extracted compounds, prominent phenolics can contribute to substantial 
woody taste and aroma. Wood attributes that confer aroma are important to characterize the sensory quality of aged spirits, such as sweety, spicy, fruity, mellow, and agreeable aftertaste (Rota et al., 2013).

The main maturation compounds, resulting from lignin degradation, are phenolic hydroxycinnamic aldehydes, represented by coniferaldehyde and sinapaldehyde, phenolic hydroxybenzoic aldehydes, represented by vanillin and syringaldehyde, and phenolic acids, represented by vanillic and syringic acids (Aylott \& Mackenzie, 2010). Nevertheless, the presence and contents of these compounds do not depend on the aging time only, but also on the wood species, toasting intensity, and level of barrel exhaustion (Quesada Granados et al., 1996).

The numbers and contents of phenolic compounds in cachaça aged in the different wood species here tested were quite different (Table 1). Phenolics were most abundant in cachaça aged in toasted cerejeira barrels, mainly represented by coumarin, hydrocoumarin, methyl anthranilate, and guaiacol. In a study of Brazilian wood extracts, these species conferred more phenolic compounds and coumarins to sugarcane spirits than oak (Silva et al., 2009), contributions that could lead to bitterer products. In the same research, $\beta$-angelica lactone, which explains herbal, sweet, anise, and nutty aromas (Vichi et al., 2005), was detected only in cachaça aged in cerejeira barrels.

Concerning cabreúva and castanheira wood, only toasted barrels provided methyl anthranilate to sugarcane spirits. This compound is associated to sweet, fruity, grape, and berry aromas (Vichi et al., 2005).

The toasting process typically increases the levels of lignin breakdown products (Cutzach et al., 1997), promoting the extraction of more phenolic compounds by cachaça during aging. Cachaça aged in non-toasted cabreúva barrels did not contain phenolic compounds. A significant increase was observed in the content of phenolic aldehydes in cachaça aged in thermal treated barrels made from cerejeira and cabreúva.

In a prior study, we investigated the effect of ten different wooden barrels on volatile and phenolic compounds present in aged sugarcane spirits. Cachaça aged in cerejeira and jequitibá rosa barrels had the highest contents of some aging marker compounds, even compared to cachaça aged in oak barrels (Bortoletto \& Alcarde, 2013)

Stevens (1991) observed that toasting intensity increased the formation of phenolic compounds in cachaça aged in oak barrels, a fact also reported by Marco et al. (1994). Campos et al. (2004) found a significant change in the composition of relevant phenolic compounds in cachaça macerated with thermal treated chips of cerejeira, cabreúva, and oak. These findings suggest that each wood species requires specific conditions during thermal treatment to positively modulate the sensory profile of aged cachaça.

Benn \& Peppard (1996) analyzed over 60 aromatic compounds in tequila extracts using GC with FlameIonization Detection (GC-FID), GC-MS, and GC-O and determined that five constituents were the most powerful odorants in this beverage: isovaleraldehyde; isoamyl alcohol; $\beta$-damascenone; 2-phenylethanol; and vanillin. Vanillin, a molecule that has low detection thresholds, is one of the most important flavor active components in aged spirits, conferring them vanilla, sweety, and sugar aromas (Lurton et al., 2012; Singleton, 1995).

In the present study, non-toasted cerejeira barrels transferred a substantial percentage of vanillin to cachaça.

\subsection{Terpenes}

Terpenes strongly influenced the characterization of cachaça aged in cabreúva barrels (Table 1). Nerolidol stood out in cachaça aged in cabreúva toasted barrels. Higher contents of other terpenes were detected in cabreúva non-toasted barrels. Overall, cachaça aged in cabreúva barrels extracted the highest variety of terpenes, including farnesol, sesquisabinene, $\alpha$-elemol, $\alpha$-cadinol, linalool, torulosol, and $\alpha$-bisabolol.

Monoterpenoids $\left(\mathrm{C}_{10}\right)$, sesquiterpenoids $\left(\mathrm{C}_{15}\right)$, diterpenoids $\left(\mathrm{C}_{20}\right)$, and triterpenoids $\left(\mathrm{C}_{30}\right)$ are secondary metabolites of plants that take part in the essential oils of plant extracts. Farnesol, nerolidol, and linalool have been traditionally used as flavorants and aroma compounds in food and perfume industries due to their characteristic flavors of herbs, spices, and flowers (Aharoni et al., 2005). 
Cardeal \& Marriott (2009) analyzed the volatile organic compounds in samples of cachaça, gin, vodka, tequila, whiskey, and flavored liqueurs and reported that aged cachaça had more terpenes ( $\alpha$-bisabolene, $\alpha$-bisabolol, nerolidol, $\alpha$-farnesol, and $\alpha$-cadinol) than the other spirits, conferring it a distinct flavor. The highest content of terpenes in aged cachaça was attributed to wood extraction and formation reactions among its own volatile compounds. Peña-Alvarez et al. (2006) quantified the most important terpenes in mezcal and tequila using Solid Phase Micro Extraction (SPME)-GC-MS. Among 28 terpenes identified, they observed remarkable contents of linalool, terpinen-4-ol, $\alpha$-terpineol, $\beta$-citronellol, eugenol, cis-nerolidol, and trans-farnesol. They also observed that terpenes were extracted during the first months of aging. Lahne \& Cadwallader (2012) investigated key odorants in agave añejo tequila using GC-O and identified 2-3-methyl-1-butanol, 2-phenylethanol, linalool, $\beta$-damascenone, guaiacol, 4-ethyl-guaiacol, eugenol, trans-isoeugenol, and vanillin as major contributors to the flavor of this spirit. Among 22 terpenes detected in 11 brandies, only nine were common to all the samples analyzed, including linalool, terpineol, citronellol, and geraniol (Zhao et al., 2009).

Terpenes are involved in flavor, aroma, and characterization of several spirits (Peña-Alvarez et al., 2006). Since these compounds have a very pleasant aroma and very low olfactory thresholds, they are perceived in tasting evaluations even in low contents (Winterhalter \& Rouseff, 2001). Peña-Alvarez et al. (2006) identified 28 terpenes in aged tequilas, including some with flavor properties such as linalool (floral, sweet), citronellol (sweet, floral), timol (warm, spicy, curry powder), and eugenol (spicy, clove). Vichi et al. (2005) identified 70 compounds in gin, including terpenes.

\subsection{Other compounds}

Furfural and 5-hydroxymethyl furfural, compounds that confer a sweet and almond-like aroma to spirits (Zhao et al., 2009), were identified in the present study in cachaça aged in toasted cerejeira barrels. The heating treatment applied to barrel staves also aggregates important characteristics to the wood that must be taken into consideration for aging distilled spirits. The level of thermal degradation influences the physical properties of wood and facilitates the extraction of wood compounds. Consequently, spirits aged in toasted barrels have their organoleptic characteristics improved, enhancing their aromatic complexity (Chatonnet \& Boidron, 1989).

Pleasant aromatic notes, described as "toasted", "caramel", "sweet", and "grilled almonds", are associated with these compounds. Wood toasting plays an important role in the formation of these compounds. Nontoasted wood presents only small contents of furfural and furfuryl alcohol (Jaganathan \& Dugar, 1999). Each maturation congener shows a different behavior related to oak species and toasting.

The approach herein proposed may help find the most important flavor active compounds in cachaça aged in tropical wood species. The determination of key aromas can contribute to predict the performance of barrels made from Brazilian wood species for aging distilled spirits. It could also be a practical way to establish quality control parameters and authenticity standards based on specific flavor compounds provided by each wood species. Moreover, the present findings pointed out to the importance of conducting broader studies on distilled beverages aged in tropical wooden barrels, as well as on the influence of different specific aromatic compounds in the chemical and sensory profile of aged cachaça.

\section{Conclusions}

Sugarcane spirits aged in barrels made from different tropical wood species exhibited different volatile flavor active compound profiles. The most predominant compounds in the samples analyzed were ethyl acetate and isoamyl alcohol. Cachaça aged in cerejeira barrels exhibited the most complex profile, mainly related to organic acids and phenolic compounds. Cabreúva barrels transferred significant aromatic terpenes to the spirits. This research presented a novel focus on the aromatic profile of sugarcane spirits aged in tropical wooden barrels. These findings stimulate further usages of tropical wood species to modulate chemical and sensory characteristics of aged spirits. The aromatic profile analysis used in this study was able 
to identify flavor compounds in aged cachaça. It could be a useful technique for standardized recognition and classification of barrels made from different tropical wood species concerning composition and complexity of aged sugarcane spirits.

\section{Acknowledgements}

This study was partly financed by the Fundação de Amparo à Pesquisa do Estado de São Paulo (FAPESP no. 2016/23211-5) and the Coordenação de Aperfeiçoamento de Pessoal de Nível Superior - Brasil (CAPES - Finance Code 001).

\section{References}

Aharoni, A., Jongsma, M., \& Bouwmeester, H. (2005). Volatile science? Metabolic engineering of terpenoids in plants. Trends in Plant Science, 10(12), 594-602. PMid:16290212. http://dx.doi.org/10.1016/j.tplants.2005.10.005

Alcarde, A. R. (2017). Cachaça: Ciência, tecnologia e arte (2a ed.). São Paulo: Edgard Blucher.

Alcarde, A. R., Souza, P. A., \& Belluco, A. E. S. (2010). Aspectos da composição química e aceitação sensorial da aguardente de cana-de-açúcar envelhecida em tonéis de diferentes madeiras. Food Science and Technology, 30(Suppl.1), 226-232. http://dx.doi.org/10.1590/S0101-20612010000500035

Aquino, F. W. B., Rodrigues, S., Nascimento, R. F., \& Casimiro, A. R. S. (2005). Phenolic compounds in Imburana (Amburana cearensis) powder extracts. European Food Research and Technology, 221(6), 739-745. http://dx.doi.org/10.1007/s00217-0050065-3

Aylott, R. I., \& Mackenzie, W. M. (2010). Analytical strategies to confirm the generic authenticity of Scotch whisky. Journal of the Institute of Brewing, 116(3), 215-229. http://dx.doi.org/10.1002/j.2050-0416.2010.tb00424.x

Benn, S. M., \& Peppard, T. L. (1996). Characterization of tequila flavor by instrumental and sensory analysis. Journal of Agricultural and Food Chemistry, 44(2), 557-566. http://dx.doi.org/10.1021/jf9504172

Bortoletto, A. M., \& Alcarde, A. R. (2013). Congeners in sugar cane spirits aged in casks of different woods. Food Chemistry, 139(1-4), 695-701. PMid:23561163. http://dx.doi.org/10.1016/j.foodchem.2012.12.053

Brasil. Ministério da Agricultura, Pecuária e Abastecimento. (2005, junho 29). Regulamenta a Lei $n^{\circ} 8.918$, de 14 de Julho de 1994, que dispõe sobre a padronização, a classificação, o registro, a inspeção, a produção e a fiscalização de bebidas (Instrução normativa n 13, de 29 de junho de 2005). Diário Oficial [da] República Federativa do Brasil, Brasília.

Brasil. Ministério da Agricultura, Pecuária e Abastecimento. (2016, agosto 23). Regulamenta a Lei $n^{\circ}$ 8.918, de 14 de Julho de 1994, que dispõe sobre a padronização, a classificação, o registro, a inspeção, a produção e a fiscalização de bebidas (Portaria nº 90, de 23 de agosto de 2016). Diário Oficial [da] República Federativa do Brasil, Brasília.

Cadahía, E., Fernández de Sinón, B., \& Jalocha, J. (2006). Volatile compounds in Spanish, French and American oak wood after natural seasoning and toasting. Journal of Food and Agricultural Chemistry, 51(20), 5924-5932.

Campos, J. O. S., Aquino, F. W. B., Nascimento, R. F., Costa, J. G. M., Keukeleire, D., \& Casimiro, A. R. S. (2004). Influence and effect of thermal treatment in elaboration of regional wood extracts for cachaça. Journal of Food Composition and Analysis, 17(2), 179-185. http://dx.doi.org/10.1016/j.jfca.2003.08.004

Carando, S., Teissedre, P.-L., Pascual-Martinez, L., \& Cabanis, J.-C. (1999). Levels of flavan-3-ols in French wines. Journal of Agricultural and Food Chemistry, 47(10), 4161-4166. PMid:10552784. http://dx.doi.org/10.1021/jf9810564

Cardeal, Z. L., \& Marriott, P. J. (2009). Comprehensive two-dimensional gas chromatography-mass spectrometry analysis and comparison of volatile organic compounds in Brazilian cachaça and selected spirits. Food Chemistry, 112(3), 747-755. http://dx.doi.org/10.1016/j.foodchem.2008.06.057

Chatonnet, P., \& Boidron, J. N. (1989). Incidence du traitement thermique du bois de chêne sur sa composition chimique. 1ere partie: Définition des paramètres thermiques de la chauffe des fûts en tonnellerie. Journal International des Sciences de la Vigne et du Vin, 23(2), 77. http://dx.doi.org/10.20870/oeno-one.1989.23.2.1725

Cutzach, I., Chatonnet, P., Henry, R., \& Dubourdieu, D. (1997). Identification of volatile compounds with a "toasty" aroma in heated oak used in barrelmaking. Journal of Agricultural and Food Chemistry, 45(6), 2217-2224. http://dx.doi.org/10.1021/jf960947d

Fan, W., \& Qian, M. C. (2006). Identification of aroma compounds in Chinese 'Yanghe Daqu' liquor by normal phase chromatography fractionation followed by gas chromatography olfactometry. Flavour and Fragrance Journal, 21(2), 333-342. http://dx.doi.org/10.1002/ffj.1621

Ferrari, G., Lablanquie, O., Cantagrel, R., Ledauphin, J., Payot, T., Fournier, N., \& Guichard, E. (2004). Determination of key odorant compounds in freshly distilled Cognac using GC-O, GC-MS, and sensory evaluation. Journal of Agricultural and Food Chemistry, 52(18), 5670-5676. PMid:15373408. http://dx.doi.org/10.1021/jf049512d

Jaganathan, J., \& Dugar, S. M. (1999). Authentication of straight whiskey by determination of the ratio of furfural to 5hydroxymethyl-2-furaldehyde. Journal of AOAC International, 82(4), 997-1001. http://dx.doi.org/10.1093/jaoac/82.4.997 
Janzantti, N. S. (2004). Compostos voláteis e qualidade do sabor da cachaça (Tese de doutorado). Universidade Estadual de Campinas, Campinas.

Lahne, J., \& Cadwallader, K. (2012). Streamlined analysis of potent odorants in distilled alcoholic beverages: The case of Tequila. In M. C. Qian \& T. H. Shellhammer (Eds.), Flavor chemistry of wine and other alcoholic beverages (pp. 37-53). Washington: American Chemical Society. http://dx.doi.org/10.1021/bk-2012-1104.ch003.

Lee, K. Y. M., Paterson, A., Piggott, J. R., \& Richardson, G. D. (2001). Origins of flavour in whiskies and a revised flavour wheel: A review. Journal of the Institute of Brewing, 107(5), 287-313. http://dx.doi.org/10.1002/j.2050-0416.2001.tb00099.x

Lurton, L., Ferrari, G., \& Snakkers, G. (2012). Cognac: Production and aromatic characteristics. In J. R. Piggott (Ed.), Alcoholic beverages: Sensory evaluation and consumer research (pp. 242-266). Cambridge: Woodhead Publishing. http://dx.doi.org/10.1533/9780857095176.3.242.

Madrera, R. R., Gomis, D. B., \& Alonso, J. J. M. (2003). Influence of distillation system, oak wood type, and aging time on volatile compounds of cider brandy. Journal of Agricultural and Food Chemistry, 51(19), 5709-5714. PMid:12952423. http://dx.doi.org/10.1021/jf034280o

Marco, J., Artajona, J., Larrechi, M. S., \& Rius, F. X. (1994). Relationship between geographical origin and chemical composition of wood for oak barrels. American Journal of Enology and Viticulture, 45(2), 192-200.

Mosedale, J. (1995). Effects of oak wood on the maturation of alcoholic beverages with particular reference to whisky. Forestry: an International Journal of Forest Research, 68(3), 203-230. http://dx.doi.org/10.1093/forestry/68.3.203

Mosedale, J., \& Puech, J. L. (1998). Wood maturation of distilled beverages. Trends in Food Science \& Technology, 9(3), 95101. http://dx.doi.org/10.1016/S0924-2244(98)00024-7

Nykänen, I., \& Nykänen, I. (1991). Distilled beverages. In H. Maarse (Ed.), Volatile compounds in foods and beverages (pp. 544-580). New York: Marcel Dekker.

Park, Y. J., Kim, K. R., \& Kim, J. H. (1999). Gas chromatographic organic acid profiling analysis of brandies and whiskeys for pattern recognition analysis. Journal of Agricultural and Food Chemistry, 47(6), 2322-2326. PMid:10794629. http://dx.doi.org/10.1021/j980954x

Peña-Alvarez, A., Capella, S., Juárez, R., \& Labastida, C. (2006). Determination of terpenes in tequila by solid phase microextraction-gas chromatography-mass spectrometry. Journal of Chromatography. A, 1134(1-2), 291-297. PMid:16996530. http://dx.doi.org/10.1016/j.chroma.2006.09.005

Piggott, J. R., \& Conner, J. M. (2003). Whiskies. In A. G. H. Lea \& J. R. Pigott (Eds.), Fermented beverage production (pp. 239262). Boston: Springer. http://dx.doi.org/10.1007/978-1-4615-0187-9_11.

Poisson, L., \& Schieberle, P. (2008). Characterization of the most odor-active compounds in an American Bourbon whisky by application of the aroma extract dilution analysis. Journal of Agricultural and Food Chemistry, 56(14), 5813-5819. PMid:18570373. http://dx.doi.org/10.1021/jf800382m

Puech, J. L. (1981). Extraction and evolution of lignin products in Armagnac natured in oak. American Journal of Enology and Viticulture, 32(2), 111-114.

Quesada Granados, J., Villalón Mir, M., López García-Serrana, H., \& López Martínez, M. C. (1996). Influence of aging factors on the furanic aldehyde contents of matured brandies: Aging markers. Journal of Agricultural and Food Chemistry, 44(6), 13781381. http://dx.doi.org/10.1021/jf9501103

Richter, H. G., \& Dallwitz, M. J. (2019, april 9). Commercial timbers: Descriptions, illustrations, identification, and information retrieval. Retrieved in 2019, March 14, from https://www.delta-intkey.com/wood/en/index.html

Rota, M. B., Piggott, J. R., \& Faria, J. B. (2013). Sensory profile and acceptability of traditional and double-distilled cachaça aged in oak casks. Journal of the Institute of Brewing, 119(4), 251-257. http://dx.doi.org/10.1002/jib.88

Silva, A. A., Nascimento, E. S. P., Cardoso, D. R., \& Franco, D. W. (2009). Coumarins and phenolic fingerprints of oak and Brazilian woods extracted by sugarcane spirit. Journal of Separation Science, 32(21), 3681-3691. PMid:20029907. http://dx.doi.org/10.1002/jssc.200900306

Singleton, V. L. (1995). Maturation of wines and spirits: Comparison, facts and hypotheses. American Journal of Enology and Viticulture, 46(1), 98-115.

Steger, C. L. C., \& Lambrechts, M. G. (2000). The selection of yeast strains for the production of premium quality South African brandy base products. Journal of Industrial Microbiology \& Biotechnology, 24(6), 431-440. http://dx.doi.org/10.1038/sj.jim.7000005

Stevens, R. (1991). Distilled beverage flavour: Recent developments, edited by J. R. Piggott and A. Paterson, VCH Publishers, 1989, No. of pages: $x+352$, ISBN 0-89573-819-8. Flavour and Fragrance Journal, 6(2), 166. http://dx.doi.org/10.1002/ffj.2730060216

The Good Scents Company Information System. (2019, march 8). Retrieved in 2019, March 14, from http://www.thegoodscentscompany.com/index.html

Ugliano, M., \& Moio, L. (2005). Changes in the concentration of yeast-derived volatile compounds of red wine during malolactic fermentation with four commercial starter cultures of Oenococcus oeni. Journal of Agricultural and Food Chemistry, 53(26), 10134-10139. PMid:16366706. http://dx.doi.org/10.1021/jf0514672

Vichi, S., Riu-Aumatell, M., Mora-Pons, M., Buxaderas, S., \& López-Tamames, E. (2005). Characterization of volatiles in different dry gins. Journal of Agricultural and Food Chemistry, 53(26), 10154-10160. PMid:16366709.

http://dx.doi.org/10.1021/jf058121b 
Vyviurska, O., Matura, F., Furdíková, K., \& Špánik, I. (2017). Volatile fingerprinting of the plum brandies produced from different fruit varieties. Journal of Food Science and Technology, 54(13), 4284-4301. PMid:29184235. http://dx.doi.org/10.1007/s13197017-2900-5

Winterhalter, P., \& Rouseff, R. L. (2001). Carotenoid-derived aoma compounds: An introduction. In P. Winterhalter \& R. R. L. Rouseff (Eds.), Carotenoid-derived aroma compounds (pp. 1-17). Washington: American Chemical Society. http://dx.doi.org/10.1021/bk-2002-0802.ch001.

Xu, Y., \& Ji, K. (2012). Moutai (Maotai): Production and sensory properties. In J. R. Piggott (Ed.), Alcoholic beverages: Sensory evaluation and consumer research (pp. 315-330). Cambridge: Woodhead Publishing. http://dx.doi.org/10.1533/9780857095176.3.315.

Zhao, Y., Xu, Y., Li, J., Fan, W., \& Jiang, W. (2009). Profile of volatile compounds in 11 brandies by headspace solid-phase microextraction followed by gas chromatography-mass spectrometry. Journal of Food Science, 74(2), C90-C99.

PMid:19323737. http://dx.doi.org/10.1111/j.1750-3841.2008.01029.x

Funding: Ministério da Ciência, Tecnologia e Inovação

$>$ Conselho Nacional de Desenvolvimento Científico e Tecnológico (CAPES - Finance Code 001); Fundação de Amparo à Pesquisa do Estado de São Paulo (FAPESP nº 2016/23211-5). 